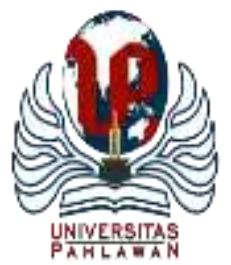

Edukatif : Jurnal Ilmu Pendidikan Volume 3 Nomor 5 Tahun 2021 Halm 3339 - 3349

EDUKATIF: JURNAL ILMU PENDIDIKAN

Research \& Learning in Education

https://edukatif.org/index.php/edukatif/index

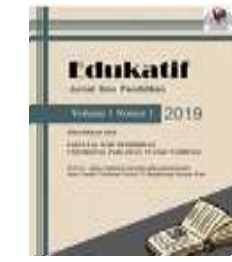

\title{
Integrasi Kearifan Lokal dalam Bahan Ajar Antropolinguistik sebagai Upaya Penguatan Pemahaman dan Karakter Mahasiswa
}

\author{
Sukarismanti $^{1 凶}$, Samsudin $^{2}$ \\ Institut Ilmu Sosial dan Ilmu Budaya Samawa Rea, Sumbawa ${ }^{1,2}$ \\ E-mail : Sukarismanti@gmail.com ${ }^{1}, \underline{\text { Syamsamsudin18@ gmail.com }}^{2}$
}

\begin{abstract}
Abstrak
Keterbatasan referensi mata kuliah antropolinguistik yang menyajikan nilai-nilai kearifan lokal menyebabkan lemahnya pemahaman mahasiswa akan nilai-nilai budaya daerah. Oleh karena itu, tujuan penelitian ini adalah mengintergasikan kearifan lokal dalam materi ajar antropilinguistik sebagai upaya penguatan pemahaman dan karakter mahasiswa program studi sastra IISBUD SAREA. Penelitian ini menggunakan metode kualitatif dengan melibatkan wawancara mendalam, observasi, dokumentasi. Hasil dari penelitian ini menunjukkan bahwa banyak kearifan lokal yang dapat diintergrasikan dalam bahan ajar antropolinguistik seperti 1) tradisi kesusastraan lisan seperti lawas, cerita rakyat, dan nyanyian rakyat; 2) tradisi permainan rakyat seperti permainan tradisional rakyat, tarian, pesta rakyat (festival kuliner, pentas seni budaya); 3) tradisi ritual adat seperti upacara pernikahan (barodak, nyorong), upacara sebelum melahirkan (bisutian), dan upacara memanen (ponan); 4) tradisi musik rakyat seperti tradisi memainkan sakeco dan gendang. Dari semua kearifan lokal tersebut merupakan kearfian lokal daeah Sumbawa yang dapat di integrasikan ke dalam bahan ajar antropolinguistik untuk menguatkan pemahaman dan karakter mahasiswa.
\end{abstract}

Kata Kunci: Kearifan Lokal, Bahan Ajar, Mahasiswa Sastra, Iisbud.

\begin{abstract}
The limitations of reference for anthropolinguistic courses presenting local wisdom values lead to a weak understanding of students about regional cultural values. Therefore, the purpose of this study is to integrate local wisdom in anthropolinguistic teaching materials as an effort to strengthen the understanding and character of students of the IISBUD SAREA literature study program. This study uses a qualitative method involving in-depth interviews, observation, documentation. The results of this study indicate that a lot of local wisdom can be integrated into anthropolinguistic teaching materials such as 1) oral-literary traditions such as lawas, folklore, and folk songs; 2) folk game traditions such as traditional folk games, dances, folk parties (culinary festivals, cultural arts performances, and others); 3) traditional rituals such as wedding ceremonies (barodak, nyorong), pre-natal ceremonies (bisutian), and harvesting ceremonies (ponan); 4) folk music traditions such as the tradition of playing sakeco and drums. Of all the local wisdom, it is Sumbawa's local wisdom that can be integrated into anthropolinguistic teaching materials to strengthen students' understanding and character.
\end{abstract}

Keywords: Local Wisdom, Learning Material, Literature Students University, Iisbud.

Copyright (c) 2021 Sukarismanti, Samsudin

$\square$ Corresponding author

Email : Sukarismanti@gmail.com

DOI : https://doi.org/10.31004/edukatif.v3i5.1253

ISSN 2656-8063 (Media Cetak)

ISSN 2656-8071 (Media Online) 
3340 Integrasi Kearifan Lokal dalam Bahan Ajar Antropolinguistik sebagai Upaya Penguatan Pemahaman dan Karakter Mahasiswa - Sukarismanti, Samsudin

DOI: https://doi.org/10.31004/edukatif.v3i5.1253

\section{PENDAHULUAN}

Kondisi sosial yang terjalin pada kalangan muda di era globalisasi yaitu terkikisnya jati diri daerah dan nasional serta munculnya jati diri baru dalam bentuk universal yang mengakibatkan hilangnya nilai budaya lokal (Kurniawan, 2018; Hodijah, 2018; Panjaitan et al., 2014; Kawuryan, 2011). Selain itu, dampak lain dari perpindahan nilai tersebut berimplikasi pada kurangnya pemahaman akan nilai-nilai budaya daerah yang menjadi penguatan pemahaman dan karakter generasi bangsa. Bila persoalan tersebut dibiarkan, maka akan berdampak pada hilangnya pemahaman budaya-budaya daerah yang menjadi kekayaan bangsa. Namun, untuk menjaga jati diri bangsa dan pemahaman akan kearifan lokal adalah dengan mengintegrasikannya dalam kurikulum pendidikan formal (Suja \& Wirta, 2012; Asmani, 2012).

Salah satu yang menjadi akar masalah adalah dapat dicari pada materi ajar yang digunakan dan teknik mengajar mata kuliah antropolinguistik yang menjadi salah satu mata kuliah yang mengkaji bahasa dan budaya. Antropolinguistik merupakan salah satu matakuliah yang mengkaji bahasa dan budaya dalam selukbeluk kehidupan manusia. Kekurangan akan materi dan teknik mengajar tersebut menyebabkan mahasiswa kurang kesadaran akan pemahaman budaya dan bahasa daerah serta lemahnya pemahaman mahasiswa pada matakuliah antropolingustik sehingga menyebabkan nilai rata-rata mereka dibawah standar.

Selain itu, dosen pengampuh matakuliah seringkali berpatokan pada bahan ajar yang termuat dalam buku pegangan yang bersifat teoritis, sehingga kurang memberikan materi pengayaan berbasis bahasa dan budaya daerah sehingga memicu ketidaktahuan mahasiswa akan kearifan lokalnya (Sudiana \& Sudirgayasa, 2015). Namun tidak dapat diingkari bahwa ada banyak yang menjadi tantangan dalam mengembangkan berbasis kearfian lokal antara lain minimnya referensi yang membahas bahasa dan budaya daerah khususnya budaya suku Samawa.

Didalam budaya suku Samawa terdapat berbagai referensi kearifan lokal yang dapat dijadikan bahan ajar atau sebagai dokumen tambahan untuk meningkatkan pemahaman mahasiswa pada matakuliah antropolinguistik. Contoh budaya daerah suku Samawa adalah sistem panggilan kepada lawan tutur, tradisi lisan Sakeco, Lawas, Baroda, dan lain sebagainya. Nilai-nilai kerafian lokal suku Samawa akan menjadi krusial apabila diintergrasikan dalam materi ajar matakuliah antropolinguistik, sebagai upaya untuk meningkatkan pemahaman mahasiswa akan matakuliah tersebut dan untuk menumbuhkan kesadaran mahasiswa akan nilai budaya daerah yang pada prinsipnya akan mengantarkan mereka menjadi manusia yang akil dan bijaksana dan mampu menuntaskan masalah-masalah yang terjalin dalam kehidupan masyarakat. Selain itu mengintgerasikan nilai kearifan lokal dalam bahan ajar dapat meningkatkan motivasi dan semangat mahasiswa dalam belajar karena materinya berhubungan langsung dengan kehiduran sehari-hari (Hartini et al., 2018). Pernyataan diatas diperkuat oleh beberapa penelitian relevan seperti penelitian yang dilakukan oleh (Rispan, 2019) yang mengatakan bahwa integrasi nilai keraifan lokal Kalosara dalam pembelajaran sejarah di sekola menengah atas (SMA) sangat krusial dan untuk menguatkan karakter peserta didik dalam menghadapi tantangan dunia sekarang dan yang akan datang dengan pemahaman moral yang dimiliki. Pada Penelitian yang dilakukan oleh (Sibarani, 2015) menunjukkan bahwa mencoba menjelaskan secara teoritis bahwa dengan meggunakan pendekatan antropolinguistik dapat memformulakan model pemeliharaan suatu tradisi lisan. Kemudian penelitian yang dilakukan oleh (Sibarani, 2013) bertujuan untuk mengambarkan sumber kearifan lokal, berbagai macam jenis kearifan lokal, dan cara menemukan kearifan lokal untuk kemudian dikaji melalui penggunaan pendekatan antropolingustik. Penelitian yang dilakukan oleh (Lubis, 2020) menunjukan bahwa melalui pembelajaran dengan menggunakan tradisi lisan Nandong, Aceh,siswa dapat mengetahui tentang nilai-nilai budaya daerahnyaseperti menghargai, taat, tekun, kerja keras, dan siap menghadapi segala tantangan. Penelitian yang dilakukan oleh (Syaputra, 2019) menilai pandagan guru terhadap integrasi nilai kearifan lokal dalam mempelajari mata pelajaran sejarah. Hasilnya menunjukkan bahwa guru mata pelajaran sejarah mengatakan bahwa intergrasi nilai kearifan lokal sangat penting dengan tiga asumsi yaitu menjaga dan 
merawat harta warisan nenek moyang, sebagai pedoman dalam menilai baik dan buruk, dan sebagai materi pengayaan serta ditemukan suatu strategi dalam mengintegrasi kearifan lokal dalam mata pelajaran sejarah yang dikuasai oleh guru, yaitu melalui pelibatan kearifan lokal dengan tema pembelajaran yang terkait. Penelitian yang dilakukan oleh (Lusiana, 2019) bermaksud untuk meningkatkan pengetahuan guru dan calon guru. Hasilnya menunjukkan bahwa integrasikan kearifan lokal dalam pembelajaran matematika itu sangat penting baik pada sisi peningkatan kemampuan siswa maupun pada melatih guru untuk kreatif dalam menggali materi ajar. Penelitin yang dilakukan oleh (Sulasmono, 2017) bermaksud untuk menggali nilai kearfian lokal dan mengintegrasikan didalam pembelajaran. Hasil penelitian menunjukkan bahwa nilai religius, sosial, toleransi, saling kerjasama, dan patrinotis lalu diintegrasikan kedalam perangkat pembelajaran. Kemudian penelitian lain yang mengitegrasikan bahan ajar berbasiswa kearifan lokal seperti penelitian yang dilakukan oleh (Sulatri et al., 2019; Barella, 2020; Pujiatna et al., 2020; Arianti, 2021; Wijaya \& Fidiastuti, 2016). Pada penelitian tersebut, peneliti mengembangan bahana ajar berbasis kearifan lokal untuk bahasa Indonesia seperti menyimak, fiksi, dan literasi.

Dari penelitian relevan diatas masih bersifat teoritis, meskipun ada sebagian peneliti yang sudah melakukan wawancara tentang ingterasi kearfian lokal dalam pembelajaran. Dalam hal ini penelitian tersebut menjelaskan bahwa mengintegrasi kearifan lokal dalam pembelajaran sangat krusial dan membantu guru menjelaskan materi ajarnya dengan mudah. Selain itu, integrasi kearifan lokal merupakan salah satu stategi untuk mengajarkan generasi penerus untuk memahami nilai-nilai yang terkandung didalam budaya daerahnya. Integrasi kearifan lokal tidak hanya dapat dilakukan pada mata pelajaran sejarah, matematika, bahasa Indonesia, akan tetap ia juga dapat diintegrasikan dalam matakuliah antropolinguistik. Jadi, berdasarkan hasil review penelitian relevan dan uraian diatas bahwa penelitian ini berbeda dengan penelitian-penelitian sebelemunya baik pada kearfian lokal yang akan diintegrasikan, maupun pada matakuliah yang menjadi objek penelitian. Jadi perbedaan penelitian ini dengan penelitian sebelumnya adalah bahwa penelitian ini menggunakan model pendekatan (Sibarani, 2013) dalam mengkaji kearfian lokal untuk diintegrasikan dalam bahan ajar antropolinguistik. Meskipun penelitian ini menggunakan pendekatan yang digunakan oleh Sibarani, namun ia berbeda dari pengkajiannya dimana penelitian yang dilakukan oleh Sibarani hanya menggali kearfian lokal sementara penelitian yang dilakukan oleh peneliti adalah menggali dan mengkaji kearfian lokal yang ada di Sumbawa. Oleh karena itu, penelitian cukup penting untuk dilakukan untuk menambah referensi matakuliah antropolinguistik serta meningkatan pemahaman mahasaiswa akan matakuliah tersebut.

\section{METODE PENELITIAN}

penelitian integrasi kearifan lokal budaya Sumbawa dalam materi ajar natropolinguistik ini menggunakan metode kualitatif dengan melibatkan wawancara mendalam, observasi, dan dokumentasi. Pada tahap wawancara, peneliti telah mewawancara secara mendalam pada tokoh-tokoh yang dianggap memahami budaya untuk menggali kearifan lokal yang berhubungan dengan fokus penelitian. Kemudian Tahap observasi digunakan untuk melakukan tinjauan langsung peristiwa budaya yang diselenggarakan oleh masyarakat suku samawa dengan cara mencari vidio kegiatan kebudayaan maupun dokumen budaya lainnya. Dan terakhir adalah dokumentasi, dokumentasi telah digunakan untuk mendapatkan informasi tambahan didalam bentuk tulisan-tulisan, arsip, dan dokumen lain yang dapat mendukung penelitian. Kemudian untuk mengganalisis data peneliti menggunakan langkah-langkah seperti yang dikemukakan oleh (Matthew, 2014) yaitu koleksi data, reduksi data, penyajian data, dan penarikan simpulan dan verifikasi. Kemudian untuk mengkaji dan mendeskripsikan data yang terkumpul pendekatan yang digunakan adalah dengan menggunakan model pendekatan yang dikembangkan oleh (Sibarani, 2013) yang melibatkan ko-teks, teks, dan konteks. Dalam kajian ko-teks melibatkan kajian paralinguistik, proksemik, gerak, dan unsur material. Kemudian teks melibatkan struktur makro (makna keseluruhan dari teks), struktur alur (pendahuluan, bagian tengan, dan 
3342 Integrasi Kearifan Lokal dalam Bahan Ajar Antropolinguistik sebagai Upaya Penguatan Pemahaman dan Karakter Mahasiswa - Sukarismanti, Samsudin

DOI: https://doi.org/10.31004/edukatif.v3i5.1253

penutup), dan strukur mikro (fonologi, morfologi, sintaksis). Dan konteks melibatkan kajian budaya, sosial, situasi dan ideologi.

\section{HASIL DAN PEMBAHASAN PENELITIAN}

Kearifan lokal yang dapat diintegrasikan dalam materi ajar antropolinguistik adalah berupa tradisi lisan atau tradisi budaya. Tradisi lisan merupakan wujud kebudayaan yang diwariskan dari generasi ke generasi melaui mulut ke telinga. Sementara tradisi budaya merupakan wujud kebudayaan dalam bentuk tindakan atau aktivitas, diciptakan dan dikomunikasikan. Oleh karena itu tradisi lisan atau tradisi budaya merupakan wujud kebudayaan yang diajarkan dari generasi ke generasi baik dalam bentuk lisan maupun dalam non verbal.

Berdasarkan hasil wawancara bahwa ada beberapa wujud tradisi lisan atau tradisi budaya suku samawa kabupaten Sumbawa yang dapat diintegrasikan dalam materi ajar antropolinguitik untuk menguatkan pemahaman dan karakter mahasiswa terhadap matakuliah antropolinguistik yaitu; (1) tradisi kesusastraan lisan seperti puisi rakyat, cerita rakyat, dan nyanyian rakyat; (2) tradisi permainan rakyat seperti permainan tradisional rakyat, tarian, pesta rakyat; (3) tradisi ritual adat seperti upacara pernikahan, upacara sebelum melahirkan, dan upacara memanen; (4) tradisi musik rakyat seperti tradisi memainkan sakeco, gendang dan alat musik lainnya.

Tabel 1. Kearifan Lokal Sumbawa

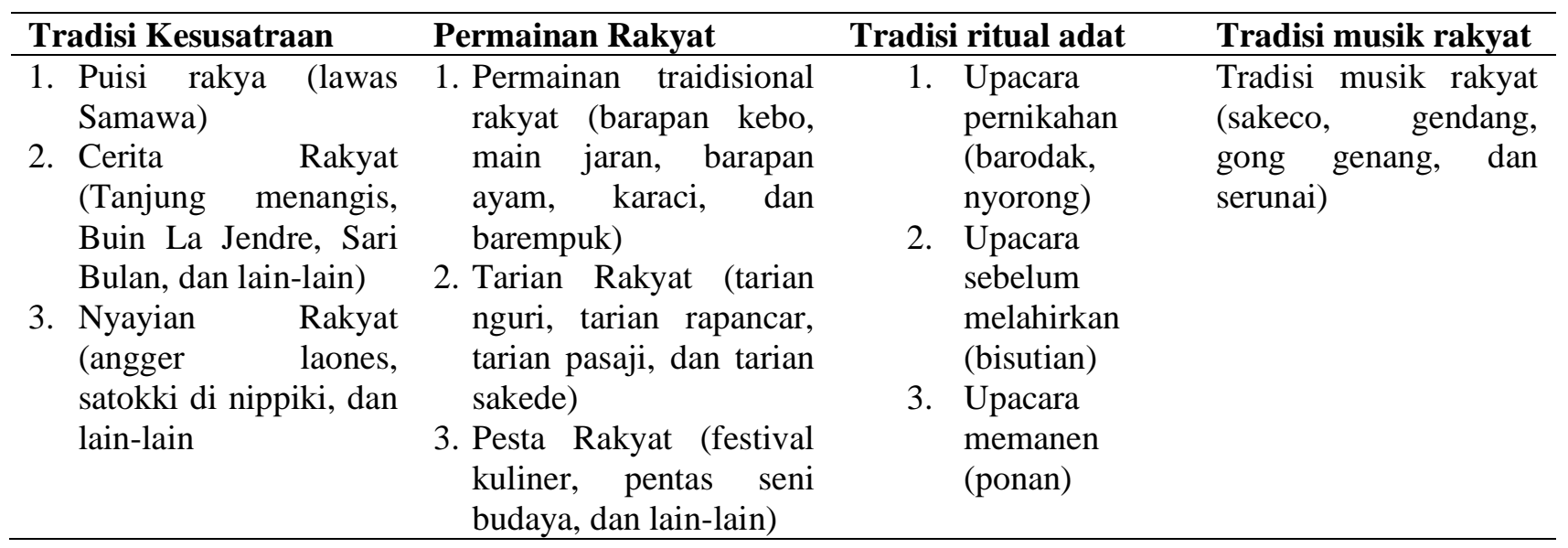

Tradisi yang terdapat dalam tabel diatas merupakan bentuk mentah wujud tradisi budaya yang masih membutuhkan kajian dengan menggunakan model pendekatan antropolingusitik yang dikembangkan oleh (Sibarani, 2013). Model pendekatan tersebut melibatkan ko-teks, teks, dan konteks. Ko-teks melibatkan paralinguistik, proksemik, gerak, dan unsur material. sementara teks mengkaji tentang struktur makro, struktur alur, dan stuktur mikro dalam sebuah teks. Dan konteks mengkaji tentang konteks budaya, sosial, situasi, dan ideologi dari sebuah wujud budaya. Namun, berdasarkan hasil analisis bahwa untuk memahami bahasa dan budaya dalam kajian antropolinguistik, maka dibutuhkan data kontekstual yang dapat dipertontonkan agar dapat memahaminya secara komprehensif.

Kemudian, dari hasil wawancara tersebut dilakukan analisis deskriptif untuk memahami kearifan lokal yang diintegrasikan dalam bahan ajar dalam konteks budaya dan bahasa seperti hasil analisis pada salah satu kearfian lokal yang dilakukan oleh peneliti dibawah ini:

\section{Sakeco}

Sakeco merupaka salah jenis musik tradisional sumbawa yang digunakan untuk menyapaikan pesan dan informasi dengan cara bernyanyi. Sakeco dapat dimainkan pada berbagai kegiatan kebudayaan sehingga ia 
3343 Integrasi Kearifan Lokal dalam Bahan Ajar Antropolinguistik sebagai Upaya Penguatan Pemahaman dan Karakter Mahasiswa - Sukarismanti, Samsudin

DOI: https://doi.org/10.31004/edukatif.v3i5.1253

memiliki berbagai macam jenis syair sakeco. Syair tersebut dapat dijadikan data untuk diintegrasikan dalam bahan ajar antropolingusitik seperti pada sakeco yang berjudul "lawan covid-19". Untuk memahami lebih dalam tentang sakeco ini, berikut adalah hasil analasis yang dilakukan oleh peneliti yang dapat diintegrasikan dalam materi ajar.

\section{Ko-teks Sakeco Lawan Covid-19 \\ Paralinguistik}

Paralinguistik berhubungan dengan bunyi dan kelancaran dalam berbicara. Pada bagian ini menilai pembicara atau penyanyi bersifat subjektif. Namun hasil penilaian dapat dikatakan benar jika pendengar menggunakan pendekat teori psikologi.

Berdasarkah hasil pegamatan dan wawancara yang dilakukan oleh peneliti bahwa tinggi dan rendahnya suara saat membawakan syair sakeco lawan covid-19 hanya sebagai hiasan yang mempercantik penyampaiannya dan tidak ada makna khusus yang terkandung didalamnya. Selain itu pemain sakeco menyampiakan syair tersebut dengan lancar yang menunjukkan bahwa pemain tersebut telah berpagalaman dan memahami syair-syairnya. Namun kondisi ini berbeda jika dilakukan pengamatan pada orang yang menyampaikan pidato.

\section{Gerak}

Pada sakeco yang berjudul lawan covid-19 yang dipersembahkan oleh mahasiswa IISBUD SAREA terdapat gerakan khas yang dipertunjukkan melalui gerakan muka. Gerakan muka yang ditunjukan merupakan gerakan ke arah kiri dan ke arah kanan. Berdasarkan hasil wawancara dengan pemain sakeco bahwa gerakan kepala tersebut adalah sebagai bentuk ekpresi yang dibawakan oleh pemain untuk menikmati suara bunyi sakeco. Artinya tidak ada makna khusus yang terkandung didalamnya. Selain itu, gekaran kepala tersebut tidak bersifat mutlak adanya bagi pemain sakeco. Ia tergantung pada siapa yang memainkannya.

\section{Proksemik}

Proksemik berhubungan dengan ruang, pengaturan ruangan, pengaturan posisi duduk, dan jarak antara pemain dengan penonton atau jarak antara orang yang satu dengan orang yang lain.

Permainan sakeco yang berjudul lawan covid-19 dimainkan diruangan terbuka yaitu dihalaman kampus IISBUD SAREA sebagai bentuk implementasi tri dharma untuk membantu pemerintah dalam mengedukasi masyarakat tentang covid-19. Selain itu, jarak antara pemain rebana yang satu dengan yang lain sekitar 2 meter karena dalam kondisi pandemi dan sebagai contoh berkomunikasi dua arah. Jarak antara pemain rabana ini tidak selamanya 2 meter karena berdasarkan hasil pengamatan dan wawancara bahwa pada umumnya pemain rebana berduduk dampingan. Artinya hal tersebut bersifat kondisional.

\section{Unsur Material}

Adapun material yang terdapat dalam kegiatan budaya ini adalah rebana, pakaian adat sumbawa, dan sapu (nama jenis pakaian adat Sumbawa).

\section{Teks}

\section{Struktur Makro Syair Sakeco}

Teks sakeco ini mengajak orang-orang untuk memutuskan mata rantai penyebaran covid-19 di Sumbawa dengan cara mentaati protokol kesehatan atau insturuksi pemerintah.

\section{Struktur Alur Syair Sakeco}

Syair sakeco disampaikan dalam bahasa daerah Sumbawa dan memiliki beberapa paragraf diantaranya adalah pendahuluan, isi, dan penutup. Masing-masing paragraf memiliki pesan yang disampaikan seperti yang dikemukakan dibawah ini; 
3344 Integrasi Kearifan Lokal dalam Bahan Ajar Antropolinguistik sebagai Upaya Penguatan Pemahaman dan Karakter Mahasiswa - Sukarismanti, Samsudin

DOI: https://doi.org/10.31004/edukatif.v3i5.1253

Pesan yang terkandung pada bagian pendahuluan ini adalah mengajak orang untuk mendengarkan saran tentang nasib negara Indonesia yang sedang mehadapai musibah yaitu wabah covid-19 yang bersumber dari negara Cina (Pendahuluan).

Pesan yang disampaikan pada paragraf kedua adalah bahwa virus corona terdapat diseluruh dunia. Ia menyebar tidak mengenal ruang dan waktu. Oleh karena itu untuk memutuskan mata rantai penyebaran virus corona ini kita harus mematuhi protokol kesehatan dengan cara diam dirumah, menghindari keramaian. Selain itu kita harus tetap memohon kepada Tuhan yang Maha Esa untuk mengahiri wabah virus corona (Konten).

Kemudian pesan yang disampaikan pada paragraf ketiga adalah bahwa virus corona merupakan suatu penyakit yang berbahaya. Ia menular melalui batuk dan bersin, sentuhan tangan. Karena penyakit ini sifatnya menular, ia memakan korban ribuan orang diseluruh indonesia. Oleh karena itu, ketika kita merasakan imun turun maka kita harus segera memperbaikin imun tubuh untuk tetap menjaga kebugaran tubuh sehingga tidak terkena virus corona (Konten).

Pesan yang disampaikan pada paragraf keempat ini adalah bahwa salah satu cara supaya tidak terkena virus corona adalah selalu menyuci tangan dengan menggunakan sabun, menjaga jarak, jangan keluar rumah jika tidak ada kepentingan mendesak, dan memakai masker (Konten).

Selain menjaga agar tedhindar dari virus corona, kita juga harus tetap berdo'a kepada Tuhan Yang Maha Esa untuk memberikan umur yang panjang dan mengahiri wabah virus corona. Selain itu masyarakat Sumbawa harus bekerjasama dengan pemerintah untuk memutuskan matarantai penyebaran virus corona (Kesimpulan).

\section{Struktur Mikro \\ Fonologi}

Kata-kata dibawah ini merupakan beberpa contoh bunyi bahasa Sumbawa

Tabel 2. Fonologi Bahasa Sumbawa

\begin{tabular}{|c|c|c|c|c|c|}
\hline No & Kata & Pengucapan & No & Kata & Pengucapan \\
\hline 1 & $\mathrm{Tu}$ & $\mathrm{Tu}$ & 11 & Odo & Odo \\
\hline 2 & Pang & Pang & 12 & Kena & Kena \\
\hline 3 & Ninta & Ninta & 13 & Katubaca & Katubaca \\
\hline 4 & Lebe & Lebe & 14 & Pang & Pang \\
\hline 5 & Kurang & Kurang & 15 & Barungan & Barungan \\
\hline 6 & Sia & Sia & 16 & Sidenreng & Sidereng \\
\hline 7 & Menong & Menong & 17 & Balong & Balong \\
\hline 8 & Bata & Bata & 18 & Batepang & Batepang \\
\hline 9 & Aran & Aran & 19 & Kasia & Kasia \\
\hline 10 & Kele & Kele & 20 & Nosoka & Nosoka \\
\hline
\end{tabular}

Berdasarkan hasil wawancara bahwa bahasa sumbawa tidak memiliki perbedaan antara tulisan dengan pengucapan. Selain itu hampir semua kata-kata dalam bahasa sumbawa khususnya kata yang miliki huruf 'e' menggunakan bunyi ' $\mathrm{e}$ ' taling daripada ' $\mathrm{e}$ ' pepet. Ia berbeda dengan kata-kata yang terdapat dalam bahasa daerah Lombok dan Bali yang sebagian besar menggunakan bunyi 'e' papat pada kata yang terdapat huruf 'e'. Oleh karena itu ia cukup mudah untuk meniru pengucapan atau mempelajari bahasa Sumbawa.

\section{Morfologi}

Hasil wawancara menunjukkan bahwa sebagian besar bahasa Sumbawa hanya mengandung imbuhan awalan (prefiks) dan pernyataan tersebut dibuktikan dengan hasil identifikasi kata-kata yang terdapat dalam syair sakeco yang berjudul lawan covid-19. Berikut adalah hasil identifikasi; 
3345 Integrasi Kearifan Lokal dalam Bahan Ajar Antropolinguistik sebagai Upaya Penguatan Pemahaman dan Karakter Mahasiswa - Sukarismanti, Samsudin

DOI: https://doi.org/10.31004/edukatif.v3i5.1253

Tabel 3. Morfologi Bahasa Sumbawa

\begin{tabular}{llll}
\hline No & Awalan (prefix) & Kata Dasar (base) & Arti Gabungan Kata \\
\hline 1 & $\mathrm{Tu}$ & Gamana (harapan) & Berharap \\
\hline 2 & $\mathrm{Ka}$ & Tokal (tempat) & Bertempat \\
\hline 3 & $\mathrm{Ba}$ & Singin (nama) & Bernama \\
\hline 4 & $\mathrm{Ba}$ & Samula (awal) & Mengawali \\
\hline 5 & $\mathrm{Sa}$ & Sopo (satu) & Menyatukan \\
\hline 6 & $\mathrm{Ba}$ & Tompok (kumpulan) & Berkumpul \\
\hline 7 & $\mathrm{Sa}$ & Rungan (kabar) & Memberi kabar \\
\hline 8 & $\mathrm{Na}$ & Kalupa (lupa) & Jangan melupakan \\
\hline 9 & $\mathrm{Ka}$ & Roa (mau) & Kemauan \\
\hline 10 & $\mathrm{Ka}$ & Takut (takut) & Ketakutan \\
\hline 11 & $\mathrm{Ma}$ & Lema (cepat) & mempercepat \\
\hline 12 & $\mathrm{Sa}$ & Peno (banyak) & memperbanyak \\
\hline
\end{tabular}

Kata-kata diatas merupakan kumpulan imbuhan (affixes) yang mengalami perubahan makna ketika ditambahkan prefiks. Untuk memahami lebih dalam pembentukan kelompok kata bahasa Sumbawa yang terdapat syair tersebut, berikut adalah hasil pengelompokkannya:

Tabel 4. Perubahan Kata Sifat ke Kata Kerja

\begin{tabular}{|c|c|c|}
\hline Prefiks & Kata Sifat & Kata Kerja \\
\hline $\mathrm{Sa}$ & Peno & Sapeno \\
\hline $\mathrm{Ma}$ & Lema & Malema \\
\hline $\mathrm{Ba}$ & Samula & basamula \\
\hline $\mathrm{Sa}$ & Rungan & Sarungan \\
\hline $\mathrm{Sa}$ & Sopo & sasopo \\
\hline
\end{tabular}

Dari hasil identifikasi dari syair tersebut bahwa terdapat 5 jenis kata yang mengalami perubahan bentuk kata dimana ada 3 prefiks 'sa' dan masing-masing 1 prefiks 'ba' dan 'ma'. Perubahan jenis kata ini mengikuti aturan morfologi. Artinya bahasa sumbawa juga memiliki aturan pembentukan kata yang sama dengan bahasa Indonesia dan bahasa Inggris.

Tabel 5. Perubahan Kata Sifat ke Kata Benda

\begin{tabular}{|c|c|c|}
\hline Prefiks & Kata Sifat & Kata Benda \\
\hline $\mathrm{Ka}$ & Roa & Karoa \\
\hline $\mathrm{Ka}$ & Takut & Katakut \\
\hline
\end{tabular}

Kemudian, untuk perubahan kata sifat ke kata benda terdapat 2 prefiks yaitu prefiks 'ka'. Perubah jenis kata ini juga mengikuti aturan yang sama dengan bahasa Indonesia dan bahasa Inggris.

Tabel 6. Perubahan Kata Benda ke Kata Kerja

\begin{tabular}{|c|c|c|}
\hline Prefiks & Kata Benda & Kata Kerja \\
\hline $\mathrm{Tu}$ & Gamana & Tugamana \\
\hline $\mathrm{Ka}$ & Tokal & Katokal \\
\hline $\mathrm{Ba}$ & Singin & Basingin \\
\hline $\mathrm{Ba}$ & Tompok & batompok \\
\hline
\end{tabular}

Selanjutnya adalah perubahan kata benda ke kata kerja. Ada 4 prefiks yang terdapat pada kelompok ini yaitu 2 prefiks 'ba' dan masing-masing 1 prefiks 'tu' dan 'ka'. Namun ada perbedaan dengan kelompok jenis 
kata yang sebelumnya dan hal ini berbeda dengan aturan yang terdapat dalam bahasa Indonesia dan Bahasa Inggris. Perubahan jenis kata atau pembentukan kata ini merupakan ciri khas bahasa Sumbawa sebagai bahasa daerah suku Samawa. Namun Aturan ini tetap dikatakan benar karena setiap bahasa memiliki aturan masingmasing.

\section{Sintaksis}

Berdasarkan hasil analisis dan wawancara bahwa teks sakeco tidak begitu banyak kalimat yang sesuai dengan rumus kalimat yang terdapat dalam bahasa lain seperti bahasa Indonesia, bahasa Inggris dan bahasa Bima dan serta bahasa daerah lainnya yang mengikuti pola subjek + predikat + pelengkap. Dari teks sakeco tersebut hanya terdapat dua kalimat yang sesuai dengan pola susunan kalimat pada umumnya yaitu sebagai berikut:

$$
\begin{array}{ll}
\underline{T a k u} & \underline{\text { bada }} \\
\text { saya } & \underline{\text { lako sia }} \\
\text { memberitaku } & \text { kalian semua }
\end{array}
$$

Pada kalimat diatas terdapat subjek, predikat, dan pelengkap. Subjek kalimat diatas adalah $T a k u$ sementara bada adalah predikat atau kata kerja dan lako sia adalah objek atau pelengkap. Kemudian pada kalimat kedua juga terdapat susunan pola kalimat yang teratur seperti dibawah ini:

$\frac{\text { Tu }}{\text { Kita }} \quad \frac{\text { ngeneng doa gama na }}{\text { berdoa }} \quad \frac{\text { ko Tuhan Yang Maha Esa }}{\text { kepada Tuhan Yang Maha Esa }}$

$T u$ adalah subjek dari kalimat teserbut. Sementara ngeneng doa gama adalah predikat dan ko Tuhan Yang Maha Esa adalah pelengkap. Dari dua kalimat tersebut sebagian besar terdapat beberapa suku kata yang memiliki satu artinya. Hal ini merupakan ciri khas bahasa Sumbawa jika dibandingkan dengan bahasa suku Mbojo yang menjadi tetangga daearahnya. Bahasa suku mbojo memilki pola susunan kalimat yang sama seperti bahasa Indonesia, bahasa Inggris, dan bahasa lainnya seperti pada contoh dibawah ini:

$\frac{\text { Nahu }}{\text { Saya }} \frac{\text { malao }}{\text { pergi }} \frac{\text { sakolah }}{\text { sekolah }}$

Kata Nahu merupakan subjek, sementara malao merupakan predikat dan sakolah adalah pelengkap. Jika dilihat dari sturktur kalimat diatas cukup sederhana jida dibandingkan dengan kalimat ayng terdapat dalam bahasa daerah Sumbawa. Selain itu, bahasa suku Mbojo sebagian besar hanya satu suku kata bentuk subjek dan predikat.

Kemudian, bahasa Sumbawa pada umumnya yang biasa digunakan baik dalam komunikasi sehari-hari maupun dalam tulisan sastra lisan miliki pola yang berbeda dalam susunan kalimatnya seperti yang terdapat dalam kalimat-kalimat diabawah ini:
1. $\frac{\text { Eya }}{\text { Akan }} \frac{k u}{\text { saya }} \frac{\text { mangan }}{\text { makan }}$
2. $\underline{\mathrm{Kam}} \underline{\mathrm{ku}} \quad \underline{\text { mangan }}$
Sudah saya makan

Kalimat diatas bukan sebuah kalimat introgatif melainkan sebuah kalimat positif. Secara struktural ia bermakna akan saya makan pada kalimat 1 dan sudah saya makan pada kalimat 2, padahal yang dimaksud dalam kalimat diatas adalah saya akan makan. Namun, kalimat introgatif yang menanyakan sudah makan dalam bahasa Sumbawa adalah seperti terdapat pada kalimat dibawah ini:

$\frac{\mathrm{kam}}{\text { sudah }}$ mangankau?

kalimat ini merupakan kalimat introgatif. Ia memiliki sturktur yang berbeda dan hal inilah yang membuat bahasa Sumbawa unik jika dibandingkan dengan bahasa lain. 
3347 Integrasi Kearifan Lokal dalam Bahan Ajar Antropolinguistik sebagai Upaya Penguatan Pemahaman dan Karakter Mahasiswa - Sukarismanti, Samsudin

DOI: https://doi.org/10.31004/edukatif.v3i5.1253

\section{Konteks}

\section{Konteks Budaya}

Teks sakeco yang berjudul lawan covid-19 dimaksudkan untuk mengedukasi masyarakat tentang bahaya wabah covid-19 dan bagaimana cara agar tidak tertular serta memutuskan mata rantai wabah covid-19. Pesan-pesan tersebut disampaikan dengan menggunakan salah satu tradisi suku samawa yaitu sakeco. Sakeco merupakan salah satu media yang cukup efektif untuk memberikan informasi atau pesan kepada masyarakat. Selain disampaikan dalam bentuk vidio, informasi dan pesan tersebut disampaikan dalam bentuk teks syair bahasa asli Sumbawa supaya orang lain dapat membaca dan memahaminya.

\section{Konteks Sosial}

Pesan-pesan atau informasi tentang wabah covid-19 disampaikan oleh 2 orang laki-laki yang berperan sebagai pemain sakeco. pesan-pesan tersebut disampaikan dengan menggunakan bahasa daerah sumbawa yang cukup mudah dipahami oleh masyarakat awam meskipun pemain sakeco atau pembawa pesan adalah mahasiswa IISBUD SAREA. Kegiatan ini tidak hanya didukung oleh kampus IISBUD SAREA tetapi ia juga didukung oleh komunitas sakeco sehingga kegiatan ini terlaksana dengan sukses. Selain itu, sakeco ini tidak hanya dinikmati oleh mahasiswa IISBUD SAREA tetapi juga oleh masyarakat suku samawa yang notabene memahami bahasa Sumbawa.

\section{Konteks Situasi}

Kegiatan penyampaian pesar atau informasi melalui sakeco ini diselenggarakan pada bulan juli tahun 2020 di kampus Institut Ilmu Sosial dan Ilmu Budaya Samawa Rea Sumbawa Besar. Teks sakeco tersebut disampaikan dengan dengan bernyanyi dan diringin oleh alat musk khas Sumbawa yaitu rebana.

\section{Konteks Ideoogi}

Di era teknologi yang cukup canggih ini Sakeco merupakan salah satu media yang cukup efektif untuk menyampaikan pesan kepada masyarakat Sumbawa dalam bentuk vidio atau siaran langsung. Karena Sakeco diyakini dan dianggap dapat menyampaikan pesan dengan efektif sehingga teks-teks tentang covid-19 akhirnya disampaikan dengan menggunakan media sakeco supaya masyarakat dapat memahamai pesan-pesan tentang bahaya penyakit covid-19 dan cara memutuskan mata rantai penyebaran.

\section{KESIMPULAN}

Berdasarkan hasil analisis, penelitian ini dapat disimpulkan bahwa ada banyak kearfian lokal yang dapat diintegrasikan dalam materi ajar antropolinguitsik untuk menguatkan pemahaman mahasiswa tentang cara menganalisis dan memahami budaya dan bahasa dengan menggunakan pendekatan antropolinguistik. Kearifan lokal tersebut adalah berupa (1) tradisi kesusastraan lisan seperti lawas, cerita rakyat (tanjung menangis, buin la jendre, sari bulan dll), dan nyanyian rakyat (angger laones, satokki di nippiki, dan lain-lain); (2) tradisi permainan rakyat seperti permainan tradisional rakyat (barapan kebo, main jaran, barapan ayam, karaci, dan barempuk), tarian (tarian nguri, tarian rapancar, tarian pasaji, dan tarian sakede), pesta rakyat (festival kuliner, pentas seni budaya, dan lain-lain); (3) tradisi ritual adat seperti upacara pernikahan (barodak, nyorong), upacara sebelum melahirkan (bisutian), dan upacara memanen (ponan); (4) tradisi musik rakyat seperti tradisi memainkan sakeco, gendang dan alat musik lainnya. Dari wujud budaya tersebut memiliki teks baik secara tertulis maupun tidak tertulis dan diselenggarakan oleh masyarakat suku Samawa pada waktu dan tempatnya masing-masing. Wujud-wujud budaya tersebut kemudian dapat dipahami dari segi lingusitik harus menggunggunakan pendekatan analisis seperti yang dikemukakan oleh Sibarani (2012) yaitu ko-teks, teks dan konteks. Ketiga hal tersebut merupakan satu kesatuan yang holistik untuk memahami budaya dan bahasa secara komprehensif. Oleh karena itu untuk dapat memahami secara komprehensif bahasa dan budaya ia memerlukan sebuah data kotekstual dalam hal ini peneliti harus melakukan pengamatan langsung pada pertunjukan budaya. Dengan menggunakan pendekatan yang dikemukakan oleh Sibarani maka akan 
3348 Integrasi Kearifan Lokal dalam Bahan Ajar Antropolinguistik sebagai Upaya Penguatan Pemahaman dan Karakter Mahasiswa - Sukarismanti, Samsudin

DOI: https://doi.org/10.31004/edukatif.v3i5.1253

ditemukan nilai dan norma kearfian lokal yang akan direvitalisasi dan dilestarikan untuk penguatan karakter mahasiswa pada khususnya dan masyarakat Sumbawa pada umumnya.

\section{UCAPAN TERIMA KASIH}

Ucapat terimakasih kami sampaikan kepada Kemdikbudristek, DRPM, dan LLdikti wilayah 8 BaliNTB yang telah memberikan bantuan dana sehingga penelitian ini selesai pada waktu yang telah ditentukan. Selain itu juga kamis ucapkan terimakasih kepada pejabat yang di IISBUD SAREA yang telah memebrikan masukan dan saran pada peneliti sehingga semuanya berkalan dengan lancar.

\section{DAFTAR PUSTAKA}

Ade. P. Panjaitan. (2014). Korelasi Kebudayaan Dan Pendidikan. Membangun Pendidikan Berbasis Budaya Lokal. Penerbit: Yayasan Pustaka Obor Indonesia.

Arianti, Delia. (2021). Kearifan Lokal Dan Implikasinya Terhadap Pembelajaran Bahasa Indonesia. Linguistik. Jurnal Bahasa \& Sastra. 6 (1) 115-123

Barella, Yusawinur. (2021). Pengembangan Bahan Ajar Berbasis Kearifan Lokal Dalam Meningkatkan Minat Membaca Mahasiswa Untan "Dinamika Pernikahan Kalimantan Barat (Melayu Sambas, Tionghoa Dan Dayak Tamambaloh). Indonesian Journal Of Learning Studies. 1(1), 39-46

E. Syaputra. (2019). Pandangan Guru Terhadap Integrasi Kearifan Lokal Dalam Pembelajaran Sejarah: Studi Deskriptif Di Beberapa Sma Di Bengkulu Selatan Dan Kaur. Indones. J. Soc. Sci. Educ., 1(1), 1-10, Available: Http://Ejournal.Iainbengkulu.Ac.Id/Index.Php/Ijsse/Article/View/1-10.

Hartini, S., Firdausi, S., Misbah, M., \& Sulaeman, N. F. (2018). The Development Of Physics Teaching Materials Based On Local Wisdom To Train Saraba Kawa Characters. Jurnal Pendidikan Ipa Indonesia, 7(2), 130-137.

Hodijah N, Ela. (2018). Pembentukan Jati Diri Melalui Kearifan Bahasa Lokal Kampung Naga Sebagai Core Ethic Value Dalam Berkomunikasi. Al-Mujaddid | Jurnal Ilmu-Ilmu Agama. 1(1), 54-73

J. S. Matthew B., Miles \& A. Michael Huberman. (2014). Qualitative Data Analysis: A Methods Sourcebook, 3rd Ed. Usa: Sage Publication, Inc.

Kurniawan, Syamsul. (2018). Globalisasi, Pendidikan Karakter Dan Kearifan Lokal Yang Hybrid Islam Pada Orang Melayu Kalimantan Barat. Jurnal Penelitian, 12(2), 317-354

Lusiana. (2019). Integrasi Kearifan Lokal Dalam Pembelajaran Matematika Dengan Pendekatan Contextual Learning. 16(3), 366-375. Doi: 10.1017/Cbo9781107415324.004.

P. Sulasmono., R. Ekosiswoyo,.,\& Sugiyo. (2017). The Integration Of Local Cultural Wisdom Values In Building The Character Education Of Students. Int. J. Educ. Res., 5(6), 151-162.

Pujiatn, Tri., Rosmaya, Elin.,\& Wahyuningsih, Nuning. (2020). Pengembangan Bahan Ajar Simak Berorientas Kearifan Lokal Untuk Meningkatkan Kemampuan Literasi Mahasiswa Pada Mata Kuliah Menyimak. Deiksis: Jurnal Pendidikan Bahasa Dan Sastra Indonesia, 7 (1). 91-97. Doi: 10.33603/Deiksis.V7i1.2804

R. Rispan And Ajat Sudrajat. 2019. Integrasi Nilai-Nilai Kearifan Lokal Kalosara Dalam Pembelajaran Sejarah Di Sma Sebagai Penguatan Karakter Siswa. J. Pendidik. Sej., 8(2), 148-169. Doi: 10.21009/Jps.082.04.

R. Sibarani. (2015). Pendekatan Antropolingusitik Terhadap Kajian Tradisi Lisan. 1(1), 1-14.

(2013). Pendekatan Antroplingustik Dalam Menggali Kearifan Lokal Sebagai Identitas Bangsa. Int. Confenrece Índonesian Stud., 274-290. 
3349 Integrasi Kearifan Lokal dalam Bahan Ajar Antropolinguistik sebagai Upaya Penguatan Pemahaman dan Karakter Mahasiswa - Sukarismanti, Samsudin

DOI: https://doi.org/10.31004/edukatif.v3i5.1253

Sekar P. Kawuryan. (2011). Mendekatkan Siswa Dengan Kearifan Budaya Lokal Melalui Ips Di Sekolah Dasar. Fip Uny

Sudiana, I Made \& I Gede Sudirgayasa. (2015). Integrasi Kearifan Lokal Bali Dalam Buku Ajar Sekolah Dasar. Jurnal Kajian Bali. 5(1), 181-200

Sulastri, Saptiana., Simarmata, Mai Yuliastri., \& Hartati, Mesterianti. (2019) Keefektifan Bahan Ajar Berbasis Kearifan Lokal Sebagai Penunjang Mata Kuliah Kajian Fiksi. Cakrawala Linguista. 2(1), 1-8

T. Lubis. (2020). Revitalisasi Tradisi Lisan Melayu Dalam Mempertahankan Eksistensi Kebahasaan : Pendekatan Antropolinguistik. No. February. Doi: 10.17605/Osf.Io/Vw9q2.

W., Suja \& Wirta, I M., (2012). Implementasi Buku Ajar Bermu-Atan Konten Sains Asli Dan Konteks Pedagogi Catur Pramana. Jurnal Pendidikan Dan Pengajar-An, 45(2): 179 - 189.

Wijaya, E. S. M., Fidiastuti, Hasminar Rachman (2016). Integrasi Kearifan Lokal Di Kecamatan Ngantang Dalam Pembuatan Lesson Plan Bagi Sekolah Dasar. Jurnal Akses Pengabdian Indonesia 1(1), 81 - 90

Https://Docplayer.Info/30004247-Integrasi-Nilai-Nilai-Kearifan-Lokal-Dalam-Pembelajaran-UntukMenanamkan-Nasionalisme-Di-Sekolah-Dasar.Html 